\title{
歩行空間の特徵把握のための歩行者流況指標に関する研究*
}

\section{A Study of Pedestrian Flow Index for Grasping Pedestrian Space's Features*}

\author{
内田 敬 ${ }^{* *}$ 又野健太郎 ${ }^{* * *} \cdot$ 辻 智香 ${ }^{* * * *}$ \\ By Takashi UCHIDA $^{* *} \cdot$ Kentaro MATANO $^{* * *} \cdot$ Tomoka TSUJI $^{* * * *}$
}

\section{1.はじめに}

\section{(1) 研究の背景}

近年、䡯い・やすらぎ・にぎわいある空間の創出など 中心市街地の活性化が重要な課題となり、街路空間の改 善例としてトランジットモールやオープンテラスの設置 などが行われている。現在、こうした街路空間の評価に は、空間密度や歩行者流量といった速度や密度に着目し た評価指標が用いられている。しかしながら、歩行空間 内にいる人の立場で考えると、整然とした流れの中にい るのか、混沌とした流れにいるのか、という歩行者周辺 の流動状況によっても評価が異なるであろう。既存の評 価指標は、この点を十分に評価することはできない。ト ランジットモールやオープンテラスなどの街路空間整備 の効果が明確にされているとは言い難く、試行錯誤のま ま行われているのが現状である。歩行者の流動状況、歩 行環境を十分に考慮した新たな歩行空間評価指標の確立 が必要である。

\section{（2）研究の経緯}

辻ら ${ }^{1)}$ は大阪市内の $2 つ の$ 歩行空間（図-1.1、図-1.2） を対象に、歩行者周辺の流動状況が与える影響を考慮し た空間評価指標に関する研究を行っている。そこでは歩 行者一人一人を水粒子、歩行者流を水の流孔と捉えるこ とで、歩行空間における回転乱れに流体力学の概念を適 用することで「渦度」として指標化することを提案して いる。さらに、対象空間で害施した主観的評価のアンケ 一ト結果と提案した流況指標の影響要因分析を通して、 渦度の空間評価指標としての有用性を示している。また、 対応する2つの流れが影響を与えあう範囲や沿道付近の 速度が遷移する範囲を境界層として定義し、流況指標の 分布図を用いて、それらの範囲が明らかにできることを 示している。

* キーワーズ : 歩行者交通、歩行空間評価、街路空間

** 正会員、博(工)、大阪市立大学大学院工学研究科

(大阪市住吉区杉本3-3-138. TEL;06-6605-2731.

FAX;06-6605-3077)

*** 学生会員、大阪市立大学大学院工学研究科

**** 正会員、修(工)、堺市建築都市局都市整備部

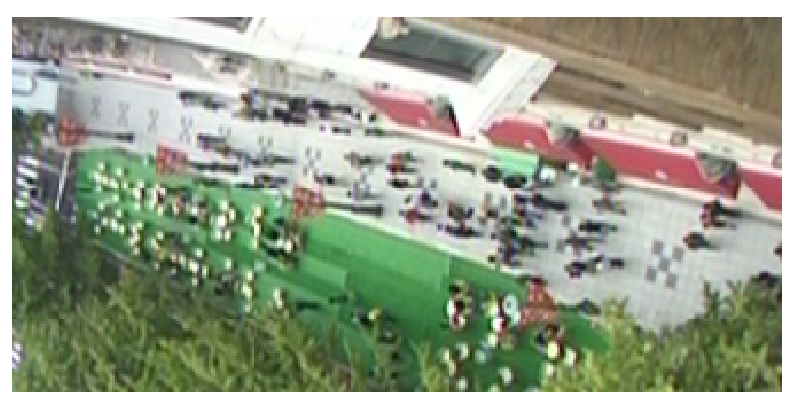

図-1.1 対象空間のビデオキャプチャ（御堂筋）

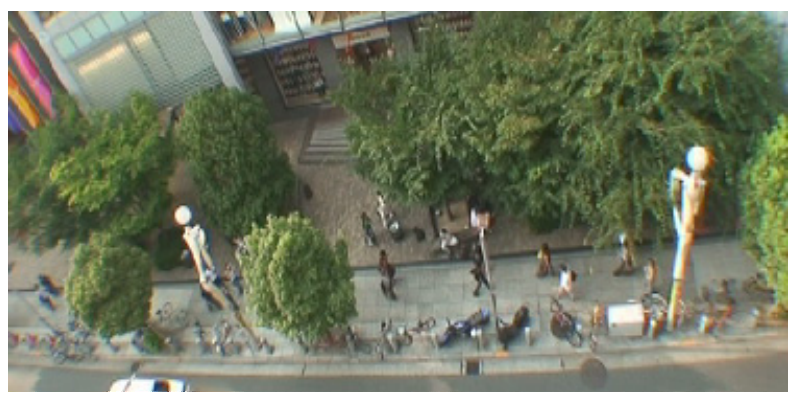

図-1.2 対象空間のビデオキャプチャ（周防町）

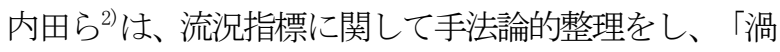
度」の可能性として以下の 2 つ事柄を示している。(1) 空間分布によれば各地点に存在する人の空間評価が、特 定の流線の積分によれば、徒歩移動者にとっての評価が 得られる。(2渦度の空間分節化機能を活用することで、 実効歩行空間の算出など、既往の歩行空間評価指標の発 展に貢献できる。

これらのことより、歩行者流況指標には 2 つの用い方 が存在すると考えられる。まず 1 つは、歩行者の視点 に立った歩行空間の居心地や満足度といった空間評価を 定量的に表現する指標としての用い方である。2つめは、 流況指標分布図によって歩行空間の分節化を行うなど、 空間の特徵を表現する指標としての流況指標である。

上記の研究は、大阪市に存在寸る「御堂筋」と「周防 町」という $2 つ の$ 実空間で得られた歩行者流動データを 用いた研究であり、歩行者流動状況は極めて複雑である。 ノイズ的流動の影響も大きいために、提案した流況指標 のみでは、分析に用いた流動状況との対応関係は必ずし も明確にはできていない。それゆえに、流況指標の可能 性として示した後者の利用方法には、様々な仮定が存在 している。 


\section{(3) 本研究の目的}

本研究は、以下の 3 つ目的を有寸る。(1)既往研究で 提案されてきた流況指標と歩行者の流動状況の対応関係 を明確にすることで、流況指標分布図による空間分節化 機能の利用方法を確立する。(2)社会実験などの効果を流 動の変化という側面から評価することを目指し、既往研 究では表現するに至らなかった歩行者の流動状況を表現 し得る指標を提案する。(3)分析時間間隔や空間サイズの 区切り方といった分析条件、歩行空間密度や歩行者速度 といった空間条件の変化は、流況指標值と密接な関係が ある。実際に歩行空間評価指標として用いる際には、こ れらを考慮したうえで、適切な条件で流況指標を算出し なければならない。そこで、分析時間間隔や空間サイズ の区切り方といった分析条件や歩行空間密度や歩行者速 度といった空間条件の変化に対する流況指標の変化につ いての定性的な知見を得る。

\section{2. 研究の方法}

\section{(1) 研究フロー}

本研究では大阪市立大学構内に設けた模擬歩行空間 （図-2.1）で行った歩行実験を通して、上述の目的に取 り組む。研究の流れは以下に示寸通りである。

(1)対象空間での歩行実験を撮影したビデオ画像から歩 行軌跡を取得して歩行者の流動状況を定量的に表現する。 (2)歩行者流動状況の特徽を表現できると考えられる流況 指標を考案する。(3)上記の(1)で定量化した速度や密度を 用いて流況指標の值を算出寸る。(4)実験流動状況之流況 指標分布の状況から、考案した流況指標の有用性を確認 する。(5)流況指標を実空間での観測結果に適用して、そ の実用可能性について初期的な検討を行う。(6)分析時間 間隔やメッシュサイズの異なるパターンにおいて流況指 標を比較し、条件の変化と流況指標分布の変化について の定性的な知見を得る。

なお、実施した歩行実験においては、速度、密度、歩 行指示という 3 点で歩行者の流動を抑制し、実際の歩行 空間における複雑な流動状況を単純化して模擬すること で、分析を簡明にすることを狙った。

\section{(2) 歩行実験の概要}

歩行実験の設計は、既往研究12) で対象としてきた空間 の特徵を考慮したうえで、実験パターンや空間サイズを 定めた。御堂筋、周防町はいずれも線的な広がりを持つ 空間であり、歩行者の主たる歩行方向が明確である。ゆ えに、模擬歩行空間に関しても線的な広がりの空間、か つ歩行方向の定まった空間とした。また、研究の背景で も述べたように、流況指標は歩行者の流動状況の違いを 考慮した空間評価指標として位置付けている。そこで、
密度や速度の違う実験パターンを設定した。

本研究で行った歩行実験の概要を表-2.1に示す。歩行 実験で再現する流動状況として、流況指標の空間分節化 機能を確認するため、一様流と対向流を、また、歩行者 の交錯についての表現可能性を検討するため、クロス流 (同方向の 2 流の交差)を設定した。また、目的(3)に示し たように、歩行空間密度や歩行者速度といった空間条件 の変化が与える影響についての知見を得るため、歩行実 験の空間条件を表-2.2に示寸 $\mathrm{A} \sim \mathrm{F}$ の 6パターンに設定 した。

\section{表-2. 1 歩行実験概要}

\begin{tabular}{|c|l|}
\hline \multicolumn{2}{|c|}{ 歩行実験概要 } \\
\hline 日時 (天候) & 2009年7月31日13時から15時 (晴れ) \\
\hline 被験者数 & 29名（うち4名は実験補助者） \\
\hline 再現流動 & 一様流、対向流、クロス流 \\
\hline パラメーター & 密度、速度 \\
\hline
\end{tabular}

表-2. 2 実験パターン

\begin{tabular}{|c|c|c|c|c|c|}
\hline \multicolumn{2}{|c|}{} & \multicolumn{4}{|c|}{ 密度指示 $\left(\right.$ 人 $\left./ \mathrm{m}^{2}\right)$} \\
\cline { 3 - 6 } & $\begin{array}{c}\text { 高い } \\
(1.7)\end{array}$ & $\begin{array}{c}\text { やや高い } \\
(1.2)\end{array}$ & $\begin{array}{c}\text { やや低い } \\
(0.8)\end{array}$ & $\begin{array}{c}\text { 低い } \\
(0.4)\end{array}$ \\
\hline \multirow{4}{*}{$\begin{array}{c}\text { 速度指示 } \\
(\mathrm{m} / \mathrm{s})\end{array}$} & $\begin{array}{c}\text { 遅い } \\
(0.5)\end{array}$ & $\mathrm{A}$ & & & $\mathrm{E}$ \\
\cline { 2 - 6 } & $\begin{array}{c}\text { 普通 } \\
(1.0)\end{array}$ & & $\mathrm{C}$ & $\mathrm{D}$ & \\
\cline { 2 - 6 } & $\begin{array}{c}\text { 早い } \\
(1.5)\end{array}$ & $\mathrm{B}$ & & & $\mathrm{F}$ \\
\hline
\end{tabular}

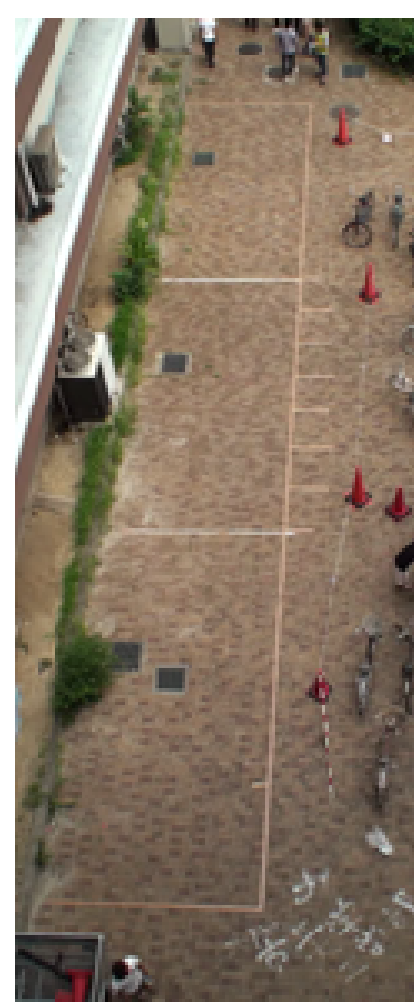

(a) 対象空間の様子

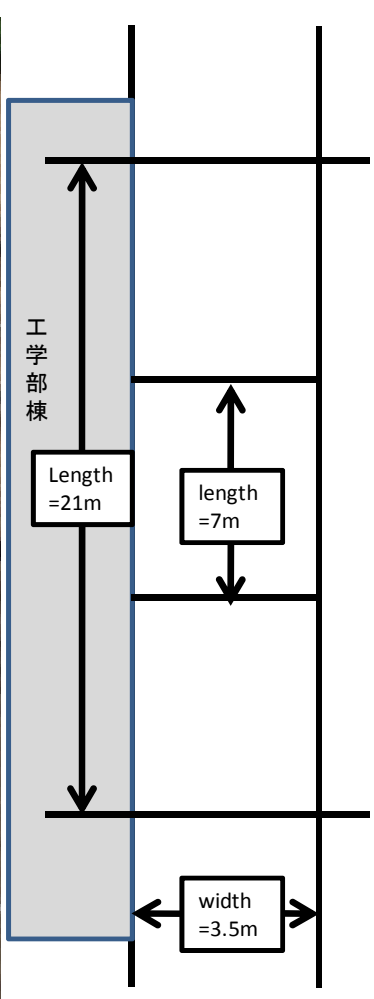

(b) 平面図
図-2.1 対象空間（大阪市立大学工学部棟中庭） 
（3）定量化手法と流況指標の算出

a) 歩行位置の取得

歩行者位置の取得手法は 3 つの段階で構成される。(1) 対象空間をビデオで撮影する。(2)対象空間に座標軸を設 定し、撮影した画像の画素座標を実空間座標へと変換す る。(3)歩行軌跡追尾ソフトDIPP MOTION-2Dを用いて、 軌跡取得時間間隔 $\Delta \mathrm{t}$ 秒ごとの歩行者の存在位置をトレ ースし（図-2.2）、実空間座標での位置座標として取得 する。

b）歩行者流動状況の定量化

歩行者流動状況の定量化は3つの段階で構成される。 (1)対象空間を $S m \times S m$ のッシンュに分割する。(2)取得した 歩行者位置座標から軌跡取得時間間隔 $\triangle \mathrm{t}$ 秒ごとの変位、 歩行速度を算出する。(3)各メッシュの歩行速度、密度を 算出する。ただし、 $\Delta \mathrm{t}$ 秒間の移動が複数のメッシュを通 過する場合は、通過メッシュに密度を均等配分していく。 c）流況指標の算出

定量化した速度や密度を用いて、各メッシュの流況指 標を算出する。図-2.3に示寸空間条件について、既往研 究で提案した指標「渦度」を例に説明する。着目mesh $(i, j)$ における洞度 $\omega$ は、次式で定義される。

$$
\omega=\left(\frac{\mathrm{u}_{(\mathrm{i}+1, \mathrm{j})}-\mathrm{u}_{(\mathrm{i}-1, \mathrm{j})}}{\Delta \mathrm{y}}-\frac{\mathrm{v}_{(\mathrm{i}, \mathrm{j}+1)}-\mathrm{v}_{(\mathrm{i}, \mathrm{j}-1)}}{\Delta \mathrm{x}}\right)
$$

\section{3. 流況指標}

\section{（1）流況指標の候補}

渦度 $\omega$ の要素である速度ベクトルの定義方向を変えて 流況指標候補 $\mathrm{A} \sim \mathrm{D}$ を設定する。図-3.1 2 と表-3.1にこれ らの特徵を示す。具体的な違いは、向かい合う速度ベク トル $\mathrm{u}_{(\mathrm{i}, \mathrm{j}+1)}$ と $\mathrm{u}_{(\mathrm{i}, \mathrm{j}-1)}$ 、または $\mathrm{v}_{(\mathrm{i}+1, \mathrm{j})}$ と $\mathrm{v}_{(\mathrm{i}-1, \mathrm{j})}$ が同方向を正 と定義するか、反対方向を正と定義するかである。この 違いによって種々の流動状況を表現することを目指して いる。さらに重みパラメータを導入して、各指標は式(2) 〜(5) で定義される。

$$
\begin{aligned}
& \mathrm{A}=\left(\frac{\mathrm{u}_{(i+1, j)}-\mathrm{u}_{(i-1, j)}}{\Delta \mathrm{y}} \times \alpha-\frac{\mathrm{v}_{(\mathrm{i}, \mathrm{j}+1)}-\mathrm{v}_{(\mathrm{i}, \mathrm{j}-1)}}{\Delta \mathrm{x}} \times \beta\right) \times \mathrm{d}_{(\mathrm{i}, \mathrm{j})} \\
& \mathrm{B}=\left(\frac{\mathrm{u}_{(\mathrm{i}+1, \mathrm{j})}-\mathrm{u}_{(\mathrm{i}-1, \mathrm{j})}}{\Delta \mathrm{y}} \times \alpha+\frac{\mathrm{v}_{(\mathrm{i}, \mathrm{i}+1)}+\mathrm{v}_{(\mathrm{i}, \mathrm{j}-1)}}{\Delta \mathrm{x}} \times \beta\right) \times \mathrm{d}_{(\mathrm{i}, \mathrm{j})} \\
& \mathrm{C}=\left(\frac{\mathrm{u}_{(\mathrm{i}+1, \mathrm{j})}+\mathrm{u}_{(\mathrm{i}-1, \mathrm{j})}}{\Delta \mathrm{y}} \times \alpha+\frac{\mathrm{v}_{(\mathrm{i}, \mathrm{j}+1)}+\mathrm{v}_{(\mathrm{i}, \mathrm{j}-1)}}{\Delta \mathrm{x}} \times \beta\right) \times \mathrm{d}_{(\mathrm{i}, \mathrm{j})} \\
& \mathrm{D}=\left(\frac{\mathrm{u}_{(\mathrm{i}+1, \mathrm{j})}+\mathrm{u}_{(\mathrm{i}-1, \mathrm{j})}}{\Delta \mathrm{y}} \times \alpha-\frac{\mathrm{v}_{(\mathrm{i}, \mathrm{j}+1)}-\mathrm{v}_{(\mathrm{i}, \mathrm{j}-1)}}{\Delta \mathrm{x}} \times \beta\right) \times \mathrm{d}_{(\mathrm{i}, \mathrm{j})}
\end{aligned}
$$

$\mathrm{v}$; 主流横断方向速度(Y軸方向速度) $\mathrm{u}$; 主流方向速度(X軸方向速度) $\mathrm{d}_{\mathrm{ij}}$; メッシュ $(\mathrm{i}, \mathrm{j})$ の密度

$\Delta \mathrm{x}, \Delta \mathrm{y} ;$ メッシュサイズ

$$
\alpha 、 \beta \text {; 重みパラメーター }(|\alpha|+|\beta|=1)
$$

既往研究1)で提案した渦度は、 $u_{(i, j+1)}$ と $u_{(i, j-1)} 、 v_{(i+1, j)}$ と $\mathrm{v}_{(\mathrm{i}-1, \mathrm{j})}$ がじちらも逆方向を正と定義しており、本研究 で定義した指標Aにあたる。しかしながら、渦度と指標 Aには2つの違いがあることに注意しなければいけない。

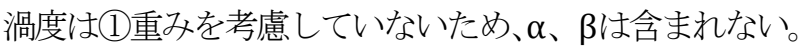
(2)密度を考慮していないため、 $\mathrm{d}_{(\mathrm{i}, \mathrm{j})}$ 項もない。本研究で、 これらのパラメーターを加えた意図は、以下の 2 点であ る。(1)歩行速度に応じて、 $\alpha 、 \beta$ を変化させることで、主 流方向と主流横断方向の特徵を顕著に表現できる。(2)密 度を考慮することで、流況指標の存在メッシュと歩行者 の存在メッシュを対応させることが可能になり、歩行環 境、歩行間隔をより適切に表現することが可能になる。

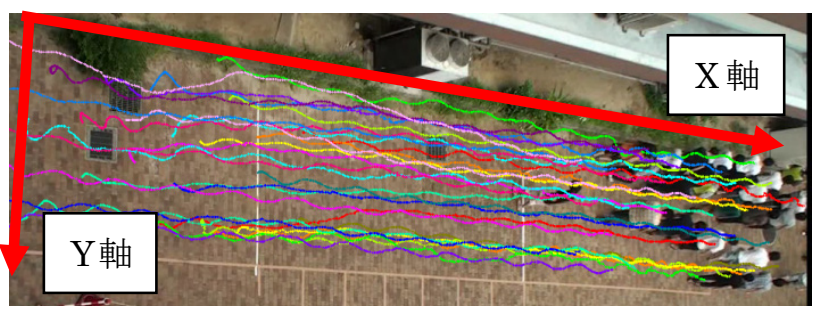

図-2. 2 歩行軌跡の取得例

\begin{tabular}{|c|c|c|c|c|}
\hline & 指標A & 指標B & 指標C & 指標D \\
\hline $\mathrm{u}_{(\mathrm{ij}+1)}$ & \multirow{2}{*}{ 逆方向 } & \multirow{2}{*}{ 逆方向 } & \multirow{2}{*}{ 同方向 } & \multirow{2}{*}{ 同方向 } \\
\hline $\mathrm{u}_{(\mathrm{i} j-1)}$ & & & & \\
\hline$v_{(i+1, j)}$ & \multirow{2}{*}{ 逆方向 } & \multirow{2}{*}{ 同方向 } & \multirow{2}{*}{ 同方向 } & \multirow{2}{*}{ 逆方向 } \\
\hline$v_{(i-1, j)}$ & & & & \\
\hline
\end{tabular}

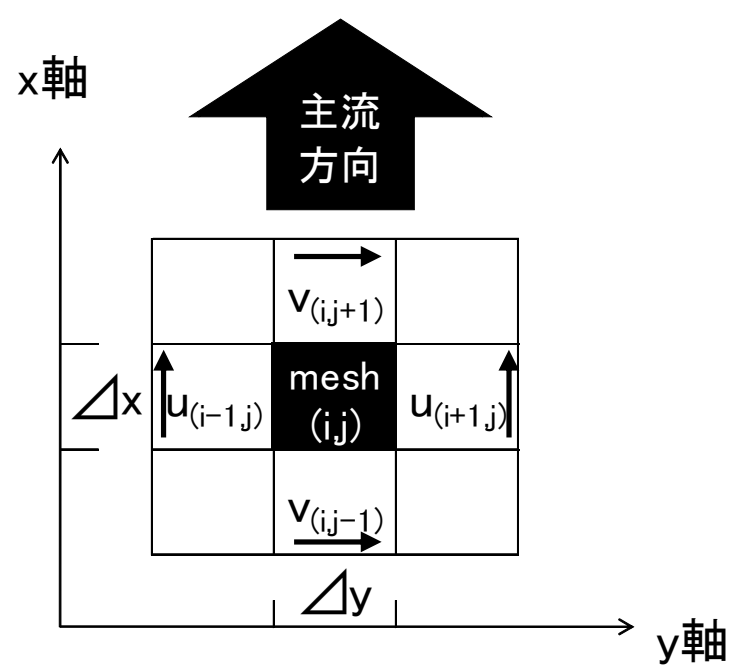

図-2.3 対象空間と定義

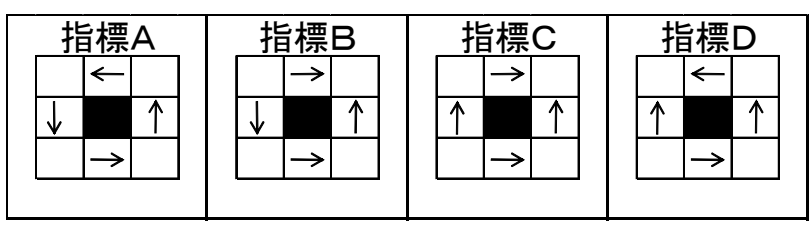

図-3.1 指標の候補

表-3.1 各指標における速度ベクトルの定義方向 


\section{（2）流動状況の特徵}

模擬空間での歩行実験において、一様流、対向流、ク ロス流という3つの流動状況を再現した。これらの流動状 沉が持つ特徴を以下に示す。

a) 一様流

・一方向の流動のみ

・主流方向速度がほぼ一様 $\left(\mathrm{u}_{(\mathrm{i}, \mathrm{j}+1)} \cong \mathrm{u}_{(\mathrm{i}, \mathrm{j}-1)}\right)$

·主流横断方向速度が0 $\left(\mathrm{v}_{(\mathrm{i}+1, \mathrm{j})} \cong \mathrm{v}_{(\mathrm{i}-1, \mathrm{j})} \cong 0\right)$

b）対向流

・二方向の流動

•主流方向速度 (絶対值) が一様 $\left(\left|\mathrm{u}_{(\mathrm{i}, \mathrm{j}+1)}\right| \cong\left|\mathrm{u}_{(\mathrm{i}, \mathrm{j}-1)}\right|\right)$

·主流横断方向速度が0 $\left(\mathrm{v}_{(\mathrm{i}+1, \mathrm{j})} \cong \mathrm{v}_{(\mathrm{i}-1, \mathrm{j})} \cong 0\right)$

・向かい合う流れが層状分布

c）クロス流

・主流方向が同じ二群の流動

・交錯地点において主流横断方向に二方向の流動

・主流方向速度がほぼ一様 $\left(\mathrm{u}_{(\mathrm{i}, \mathrm{j}+1)} \cong \mathrm{u}_{(\mathrm{i}, \mathrm{j}-1)}\right)$

・交錯地点ではグループ挙動が卓越

\section{（3）流況指標の特徵}

上記（1）の通り、向かい合う速度ベクトルの方向に よって指標は定義される。向かい合うべクトルの定義方 向が流況指標の值に与える影響を表-3.2、表-3.3に示寸。 向かい合う速度ベクトルの定義方向が同方向であれば、 整然流動の内部で大きな值を示し、逆方向であれば、対 向や速度差の生じている場所など、速度が遷移する範囲 で大きな值を示す。これらを、組み合わせることで種々 の流動状況の特徴を表現した。

本研究で対象としている空間は主流方向速度が卓越し た空間であることに留意しなければいけない。ゆえに、

表-3. 2 に示す特徴を優先的に考えたのち、表-3.3に示す 特徵を考え合わせる (表-3.4)。たとえば、 $\mathrm{u}_{(\mathrm{i}, \mathrm{j}+1)}$ と $\mathrm{u}_{(\mathrm{i}, \mathrm{j}-1)}$ 、 $\mathrm{v}_{(\mathrm{i}+1, \mathrm{j})}$ と $\mathrm{v}_{(\mathrm{i}-1, \mathrm{j})}$ の両者が同方向を定義されている場合、つ まり指標Cにおいては、表-3. 2 に示寸特徴によって、特 徵表現(1速度一定範囲が把握できる。次に、主流方向で は小さな值を示寸速度遷移範囲においては、表-3.3に示 寸特徴によって、特徴表現(2)主流横断方向の流動が把握 できる、といった具合である。同様に、各指標によって 表現可能な流動状況を表-3.4に示した。

指標 $\mathrm{A} 、 \mathrm{D}$ に関しては、注意を要する。指標 $\mathrm{A}$ は、向 かい合うベクトルが逆方向を示寸ことから既往研究でも 利用されてきたように、特徵表現のほかに、歩行者流動 状況の乱れを表寸指標としての利用が挙げられる。また、 指標 $\mathrm{D}$ は、指標 $\mathrm{B}$ のX軸、Y軸を反転した指標と同様であ ることから、主流方向だけでなく、主流横断方向に対し ても主流が生じる場合、つまり三叉路などにおいては特 徵表現(2)として速度一定範囲の主流縦断方向の流動が把 握できる。

\section{（4）流況指標の適用}

以上のように、本研究で考案した流況指標の特徵（上 記(1)、(3)）と流動状況の特徴（上記(2)）から、種々 の流動状況の把握・表現が可能だと考えられる。これら の流況指標を適用すべき流動状況を整理すると、指標 $\mathrm{A}$ は速度遷移範囲の抽出、指標 $\mathrm{D}$ は速度一定範囲の抽出が

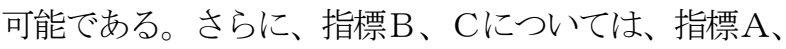
Dによって抽出された流動状況に対して適用することで、 横断方向流動を把握することができる。図-3.2に示すフ ローを用いることで、種々の歩行空間の特徽を表現する ことができる。 $\mathrm{u}_{(\mathrm{i}, \mathrm{j}+1)}$ と $\mathrm{u}_{(\mathrm{i}, \mathrm{j}-1)}$ が同方向の場合、横断方 向流動の影響を受けることが考えられるので、第 1 段階 にあたる流動状況の抽出には、指標A、Dを用いている。 なお、主流方向速度と横断方向速度の大きさによっては、 重みパラメーターを調整する必要がある。

\section{表-3. 2 主流方向における指標の特徵}

\begin{tabular}{|c|c|c|c|}
\hline \multirow{2}{*}{\multicolumn{2}{|c|}{$\begin{array}{c}\text { 速度ベクトル } \\
\text { の向き }\end{array}$}} & \multicolumn{2}{|c|}{ 主流方向 } \\
\hline & & 整然とした流動 & 混沌とした流動 \\
\hline$u_{(i j+1)}$ & \multirow{2}{*}{ 同方向 } & \multirow{2}{*}{ 大 } & \multirow{2}{*}{ 小 } \\
\hline$u_{(i j-1)}$ & & & \\
\hline$u_{(i j+1)}$ & \multirow{2}{*}{ 逆方向 } & \multirow{2}{*}{ 小 } & \multirow{2}{*}{ 大 } \\
\hline$u_{(i j-1)}$ & & & \\
\hline
\end{tabular}

表-3. 3 主流横断方向における指標の特徵

\begin{tabular}{|c|c|c|c|}
\hline \multirow{2}{*}{\multicolumn{2}{|c|}{$\begin{array}{c}\text { 速度ベクトル } \\
\text { の向き }\end{array}$}} & \multicolumn{2}{|c|}{ 主流方向 } \\
\hline & & 整然とした流動 & 混沌とした流動 \\
\hline$v_{(i+1, j)}$ & \multirow{2}{*}{ 同方向 } & \multirow{2}{*}{ 大 } & \multirow{2}{*}{ 小 } \\
\hline$v_{(i-1, j)}$ & & & \\
\hline$v_{(i+1, j)}$ & \multirow{2}{*}{ 逆方向 } & \multirow{2}{*}{ 小 } & \multirow{2}{*}{ 大 } \\
\hline$v_{(i-1, j)}$ & & & \\
\hline
\end{tabular}

表-3. 4 流況指標の特徵

\begin{tabular}{|c|c|c|}
\hline & 特徵表現(1) & 特徵表現(2) \\
\hline 指標A & \multirow{2}{*}{$\begin{array}{c}\text { 速度遷移範囲 } \\
\text { (対向部·流動端部) }\end{array}$} & （歩行者乱れ） \\
\hline 指標B & & $\begin{array}{c}\text { 速度一定範囲 } \\
\text { の横断方向流動 }\end{array}$ \\
\hline 指標C & \multirow{2}{*}{$\begin{array}{l}\text { 速度一定範围 } \\
\text { (一様な流動部) }\end{array}$} & $\begin{array}{c}\text { 速度遷移範囲 } \\
\text { の横断方向流動 }\end{array}$ \\
\hline 指標D & & （三叉路） \\
\hline
\end{tabular}

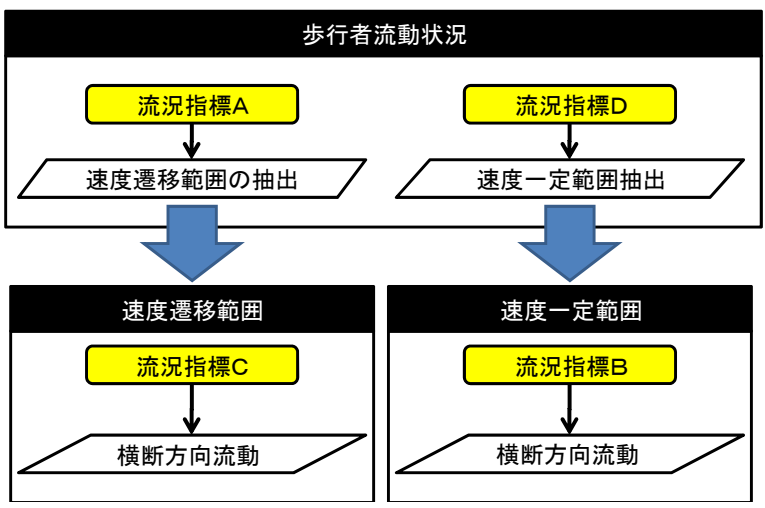

図-3.2 流況指標の適用フロー 


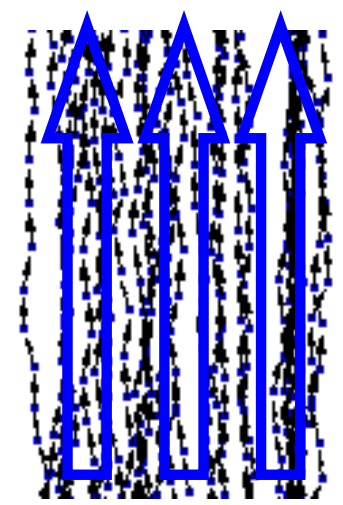

a) 一様流

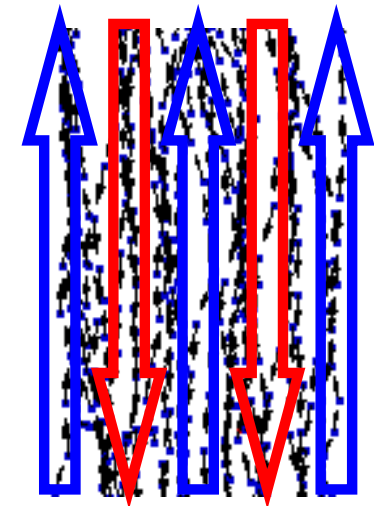

b) 対向流

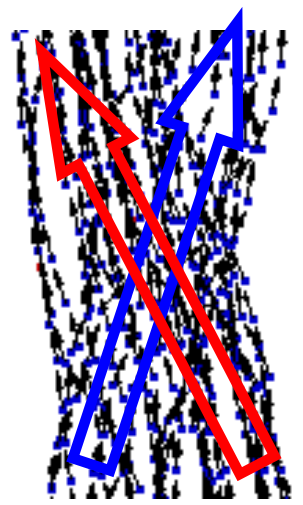

c）クロス流

図-4. 1 歩行軌跡（2009 年 7 月 31 日、歩行実験パターンC)

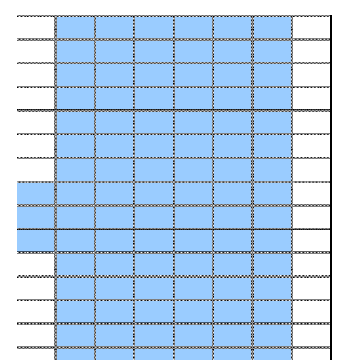

a）指標Dの分布状況 (一様流)

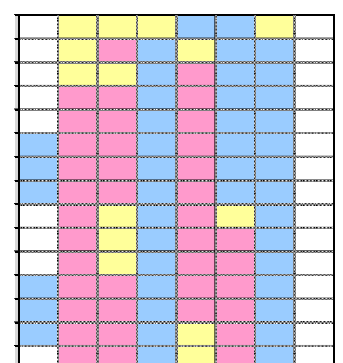

b) 指標Aの分布状況（対向流）

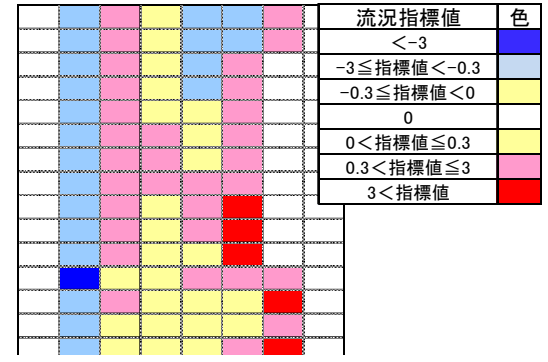

c）指標Bの分布状況（クロス流）

図-4.2 流況指標分布図（2009 年 7 月 31 日、歩行実験パターンC、 $\Delta \mathrm{t}=0.5 \mathrm{sec、メッシュサイズ} 0.5 \mathrm{~m}$ ）（注1）

4. 適用結果

\section{（1）実験空間への適用}

ここでは、提案した流況指標の分布状況とベクトル表 示した空間流動状況を比較して流況指標の有用性を確認 する。実験パターンC（表-2.2参照）を例に、流動状況 と指標分布状況の関係を以下に示す。

a）一様流

速度一定の同一方向流動のみで構成されている（図 -4.1a）)ことから、流況指標Dを用いて表現する。流況 指標分布は正の值を示し、同一色で構成されるはずであ る。図-4. 2a)を見ると、この特徵は表現できている。

b）対向流

流動方向が二方向存在するため、極端な速度遷移が存 在する。よって流況指標Aを用いて表現する。流況指標 は正と負が交互に存在し、青色と赤色の層が交互に分布 するはずである。図-4. 2b) を見ると、実際の流動の対向 流の層の分布と同椂に正と負が交互に存在している。よ って、対向流の特徵は流況指標Aで表現できている。

c）クロス流

主流方向速度はほぼ一定であるが、一様流との相違点 として、主流横断方向流が存在している。図-3.2に従い、 速度一定範囲における横断方向変化は流況指標Bを用い て表現する。流況指標は交錯地点においては、その交錯 角度や交錯するグループ挙動によっても多少変動はある が、正、もしくは、負の分布が斜めに分布すると考えら れる。図-4. 2c) を見ると、赤色が中心付近に左上に向か

って、また、青色が右上に向かって斜めに分布している ことが分かる。図-4.1c)に示した歩行軌跡を見ると、左 側への移動グループが大きいことがわかる。よって、流 況指標Bによってクロス流、および交錯の様子を表現でき ている。なお、流況指標Bに関しては横断方向への変化を 顕著にするため、 $\alpha: \beta=1: 2$ とした。

d）他指標での表現

流況指標Bによるクロス流の表現は、指標Dによって 一定方向流である範囲を抽出したのちに行うことが前提 である。そこで、クロス流における流況指標 $\mathrm{D}$ の分布状 況を図-4.3に示した。指標分布図から、クロス流であっ ても同方向流であれば、一様流動部として抽出できるこ とがわかる。

次に一様流（図-4.1a））における流況指標Bの分布状 況を図-4.4に示す。流況指標Bによって赤又は青に色が つけられる範囲は横断方向の流動が大きいときのみであ るが、実際に一样流の範囲は黄色 1 色で示されており、 流況指標の相互補完的関係が確認できる。

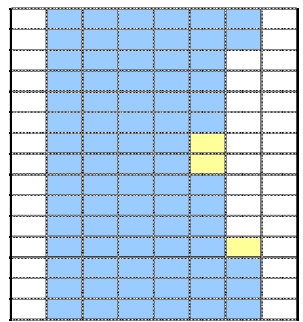

図-4.3指標Dでのクロス流

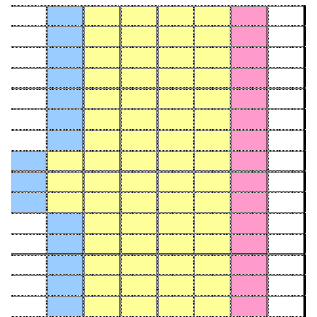

図-4. 4指標Bでの一様流 


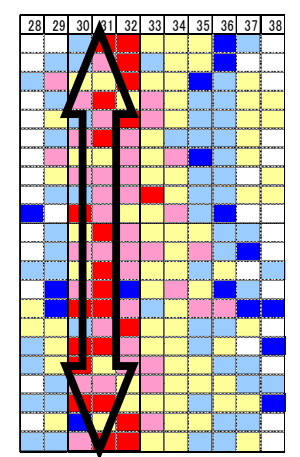

a）指標 $A$ の分布状況

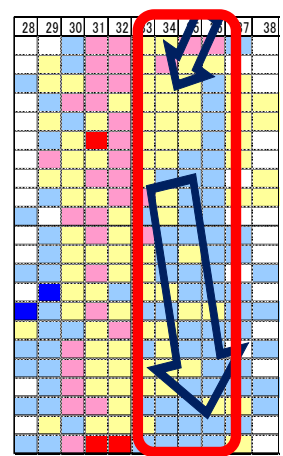

b）指標Bの分布状況

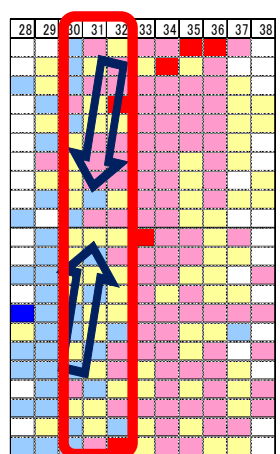

c）指標Cの分布状況

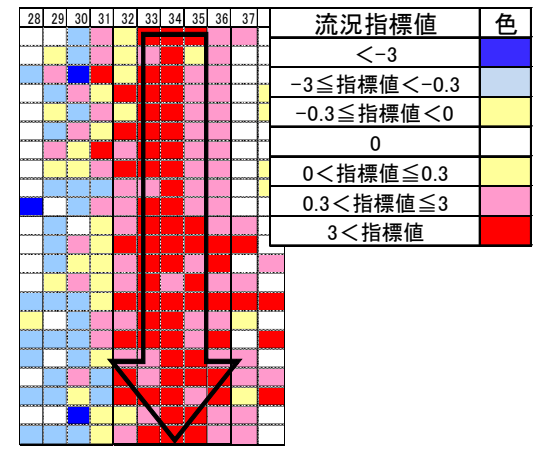

d）指標Dの分布状況

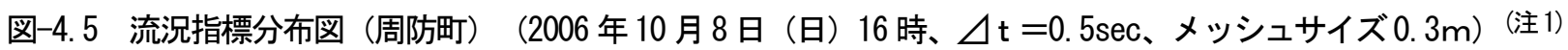

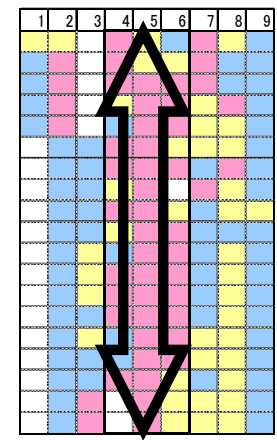

a) 指標Aの分布状況

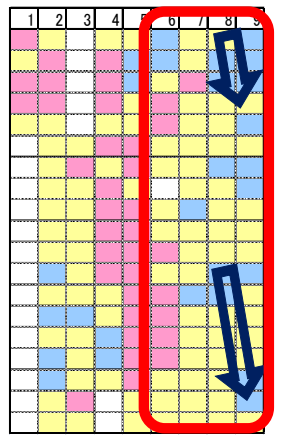

b) 指標Bの分布状況

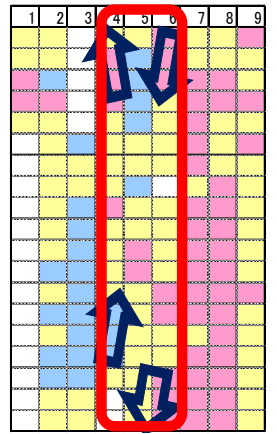

c) 指標Cの分布状況

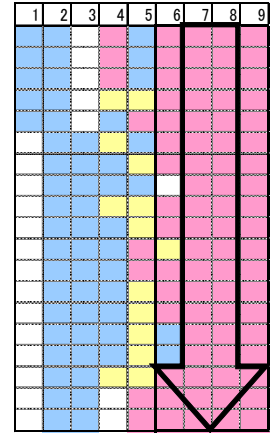

\begin{tabular}{|c|c|}
\hline 流況指標値 & 色 \\
\hline$<-3$ & \\
\hline$-3 \leqq$ 指標值 $<-0.3$ & \\
\hline$-0.3 \leqq$ 指標値 $<0$ & \\
\hline 0 & \\
\hline $0<$ 指標值 $\leqq 0.3$ & \\
\hline $0.3<$ 指標値 $\leqq$ & \\
\hline $3<$ 指標値 & \\
\hline
\end{tabular}

d）指標Dの分布状況

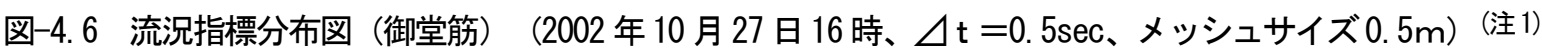

\section{（2）実空間への適用}

既往研究1) 2)で適用してきた実際の歩行空間である周防 町、御堂筋において、新たに提案した流況指標の分布状 況を図-4.5、図-4.6に示す。これらから流動状況把握の 可能性を検討寸る。

a) 周防町 (図-4.5)

指標 $\mathrm{A} の$ 分布状況を見ると、列30〜32の範囲において 赤色が带状に分布している。ゆえに、この地点には二方 向の流れが影響を与えあう対向流が存在していることが 分かる。つぎに指標 $\mathrm{D}$ 分布状況を見ると、列 33 ～36の 範囲において赤色が带状に分布している。ゆえに、この 地点には下向きの一様流が存在していることがわかる。

流況指標 $\mathrm{A} 、 \mathrm{D}$ から一様流と対向流の範囲が抽出でき た。適用フロー（図-3.2）に従って、抽出された範囲に おいて流況指標B，Cを適用し、その流動の詳細を見る。 対向流内部の横断流動については、指標Cを用いて把握 する。指標Cの分布状況を見ると、中心より下半分の地 点において青色分布が、中心より上半分において赤色分 布が確認できる。従って、対向流内部で赤色の地点は左 向き移動を、青色の地点は右向き成分を伴う流動であり、 矢印で示したような流動が存在すると考えられる。一様 流内部の横断流動は、指標 $\mathrm{B}$ を用いて把握する。指標 $\mathrm{B}$ の分布状況から、上部の赤色地点では左向き移動を、下 部の青色地点では右向き移動を伴う移動であり、矢印で 示したような流動が確認できる。
これらを総括して把握できる特徵を以下に示す。(1)左 側が上向き、右側が下向きの左側通行、(2)対向部の幅が3 メッシュ程度の境界層が 1つ存在、(3)各図の右上に沿道 建物の流出入口があることから、一様流内部において流 出入口を避けながら歩行していることが把握できる、(4) 対向流部においても比較的大きな横断方向流動が存在し ている。

b) 御堂筋（図-4.6)

指標 $\mathrm{A}$ 分布から列 $4 \sim 6$ の範囲で対向流が存在してい ることが、指標Dの分布状況から列7〜9の範囲において 下向きの流動が存在していることがわかる。対向流内部 の横断方向流動は、指標 $\mathrm{C}$ の分布状況から、上部では2 つの左へ向から流動の存在とその間の右側へ向から流動 が存在していることを把握できる。一様流内部の横断方 向流動は、指標Bの分布状況から、列8～9の上部および 下部に右方向へと向かう流動が存在していることが把握 できる。

これらを総括して把握できる特徵を以下に示す。(1)左 側が上向き、右側が下向きの歩行、(2)対向流部の幅が 3 メッシュ程度の境界層が 1つ存在、(3)対向流部の広がり に応じて、対向流部を避ける流れが存在、(4)対向流部に おいては横断方向への流動はあまり見られない。

しかしながら、対向流部における具体的な流動把握は 指標Cによっても困難であり、この流動の詳細な把握が 可能な指標の考究は、これからの課題である。 
表-5. 1 歩行軌跡取得間隔 $\angle \mathrm{t}$ （フレーム間隔）の変化と流況指標の変化

\begin{tabular}{|c|c|c|c|c|c|}
\hline$\Delta \mathrm{t} \quad$ (フレーム間隔) & $0.5 \sec (15$ フレーム) & 1. Osec & 30フレーム) & \multicolumn{2}{|c|}{ 2. Osec (60フレーム) } \\
\hline \multirow{5}{*}{$\begin{array}{c}\text { 実験パターンAにおける } \\
\text { 流況指標Bの分布状況 } \\
\text { (クロス流 })\end{array}$} & $\square$ & & & & 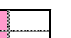 \\
\hline & + & 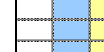 & 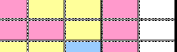 & $=$ & + \\
\hline & $=3$ & 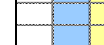 & m & 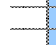 & 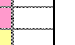 \\
\hline & 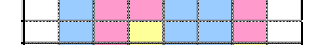 & - & 5 & $=$ & $y_{0}$ \\
\hline & $\begin{array}{lll:} \\
\end{array}$ & 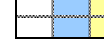 & 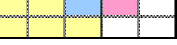 & & 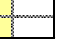 \\
\hline
\end{tabular}

表-5.2 メッシュサイズの変化と流況指標の変化

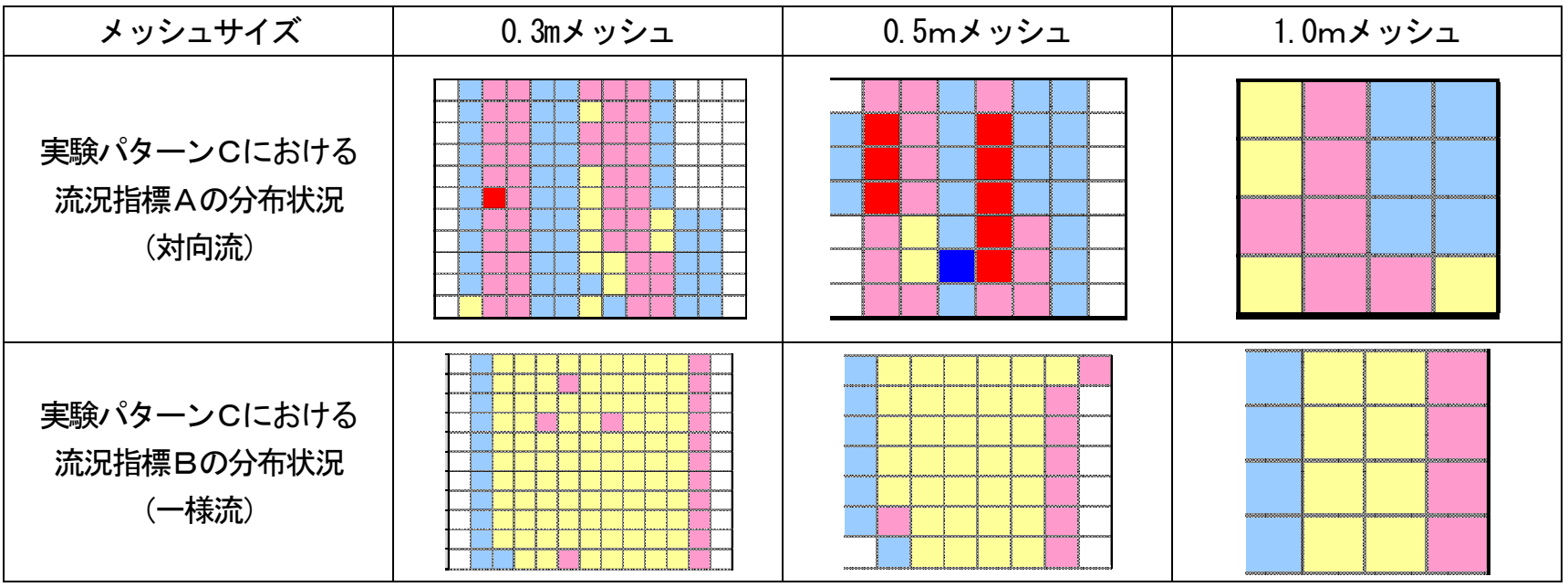

\section{5. 諸条件変化と流況指標}

\section{（1）流況指標に影響を与える要因}

流況指標の值は、流動ベクトルを数值化した速度と密 度（各メッシュに1つの值）によって定められる。流動 状況が異なると、各メッシュに数值化される速度と密度 が変化するため、指標の分布状態も異なった様相を示す。 前章では、流動状況の特徵と流況指標の分布状況の関係 性を明らかにすることで、流況指標から流動状況の特徵 を把握できることを確認した。しかしながら、分析条件、 たとえば歩行軌跡取得間隔や空間メッシュサイズによっ ても速度や密度は異なることが考えられる。

\section{（2）分析条件の変化と流況指標}

a) 歩行軌跡取得間隔 $\angle t$

歩行軌跡取得間隔 $\Delta \mathrm{t}$ をきくすると、主流横断方向一 のずれや速度変化などの微細な流動状況を省いた歩行軌

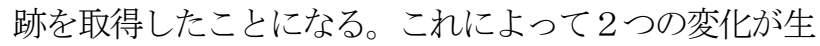
じる。(1)歩行速度 $u$ とvの分布状況が変化する。具体的に は $\Delta \mathrm{t}$ をきくすると速度を平滑化する時間的範囲が大 きくなり、急激な速度変化などが省かれ、 ると頭の摇れなどの細かな動きの速度まで反映してしま う。(2)軌跡ベクトルの変化による歩行者通過メッシュ数 の変化によって、密度の分布状況が異なる。 b）メッシュサイズ変化と流況指標

対象空間のメッシュサイズ (区切り) を変化させるこ とによって、空間的に統合寸る範囲が大きくなる。これ によって(1)歩行速度 $u$ とvの分布状況が変化する。具体的 にはメッシュサイズを大きくすると速度を平滑化する空 間的範囲が大きくなり、場所別の詳細な移動は省かれ、 メッシュサイズを小さくすると頭部の位置などの場所別 の些細な動きを反映してしまう。

c）模擬空間での確認とまとめ

表-5.1の歩行軌跡取得間隔 $\triangle \mathrm{t}$ 別の指標 $\mathrm{B}$ の分布から、 取得間隔を大きくすればするほど、主流横断方向の変化 を把握できなくなることがわかる。これは、1つのベク トルを密度 1 として、通過メッシュに均等配分すること から生じる密度変化による影響が大きいと考えられる。

表-5.2のメッシュサイズ別の流況指標Aの分布から、 メッシュサイズを小さくするほど、混合部の幅など詳細 な流動状況を把握できることが確認できる。しかしなが ら、メッシュ分割を小さくしすぎると各場所での些細な 流動による影響を表現してしまう。これらの影響を表現 する必要性に応じて設定するのがよいと考えられる。

\section{（3）空間条件変化と流況指標}

a）速度の異なる空間

類似流動で速度が異なる場合について考察する。表 -5.3に示寸ように速度が異なると、速度遷移領域におい 
て、色の濃度が異なる。一様流においても同様である。 速度によって指標值の大きさは異なるが、速度の大小に 関わらず、流況指標による特徵表現は可能である。

b）密度の異なる空間

同様に、密度が異なる場合について考察する。表-5.4 に示すように密度が減少すると、色つきの值が生じる。 これは、密度の減少により、特異な流動の影響が顕著に 表れるからだと考えられる。よって、密度の低い空間に 適用する場合には、流動状況を捉えることが可能なメッ シュサイズへと拡大する必要がある。

\section{6. おわりに}

新たな歩行者流況指標を提案することで、主流・混合 流のみならず、横断方向の変化を表現することができた。 また、これら指標が複雑な流動状況を示寸実空間の流動 状況においても指標適用フローに従って組み合わせるこ とで、適用可能であることを示した。

こうした流況指標の特徴把握機能は、社会実験の有無 などによる流動状況の違いを比較する指標として利用で きると考えられる。たとえば、放置自転車の撤去やオ一 プンテラスによる音楽演奏が流動に与える影響の評価と いう意味で用いることが可能だろう。

これら指標を用いる際には、重みパラメーター $\alpha 、 \beta$ の設定が必要である。対象空間の大きさや主流方向速度 や密度といった歩行環境によって、重みパラメーターを 調整することが必要である。指標としての確立を目指す には、これら諸条件とパラメーターの設定の定量的な関
表-5. 3 速度の変化と流況指標の変化

\begin{tabular}{|c|c|c|}
\hline $\begin{array}{c}\text { 実験パターン } \\
\text { (速度) }\end{array}$ & $\begin{array}{c}\text { 実験パターンA } \\
(0.5 \mathrm{~m} / \mathrm{s})\end{array}$ & $\begin{array}{c}\text { 実験パターンB } \\
(1.5 \mathrm{~m} / \mathrm{s} \text { 実験 })\end{array}$ \\
\hline 指標A & 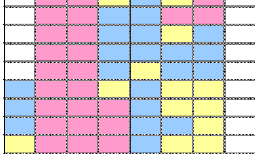 & 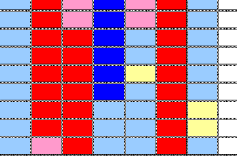 \\
\hline
\end{tabular}

表-5. 4 密度の変化と流況指標の変化

\begin{tabular}{|c|c|c|}
\hline $\begin{array}{c}\text { 実験パターン } \\
\text { (密度) }\end{array}$ & $\begin{array}{c}\text { 実験パターンB } \\
\left(1.7 人 / \mathrm{m}^{2}\right)\end{array}$ & $\begin{array}{c}\text { 実験パターンF } \\
\left(0.4 人 / \mathrm{m}^{2}\right)\end{array}$ \\
\hline 指標B & - & \\
\hline
\end{tabular}

係を明らかにする必要がある。また、対向流内部の移動 に関しては、今後、詳細な挙動の表現方法を考案しなく てならない。

（注 1） 5. に示すように、分析条件、すなわち歩行軌跡取得 間隔、メッシュサイズによって指標值の分布の様相は異なる。 4.においては、種々の分析条件を試した結果、分布図として 特徵が判読しや寸いものを図4-2, 5, 6として提示した。

\section{参考文献}

1) 辻智香, 内田敬 : 街路空間の主観的評価における歩行者流動効 果の定量化，土木計画学研究·講演集，Vol. 32 (CD-ROM), 4pp., 2005.

2)内田敬, 辻智香 : 街路歩行者流の流況可視化と新L O S 指標の 提案，土木計画学研究・講演集, Vol. 35 (CD-ROM), 4pp., 2007.

\section{歩行空間の特徵把握のための歩行者流況指標に関する研究*}

内田 敬** 又 又野健太郎*** 辻 智香****

近年、中心市街地の活性化が重要な課題となり、街路空間の改善例として、オープンテラスの設置などが行 われている。街路空間評価は、空間密度や歩行者の流量といった指標で行われているが、多方向の流れが混在 している空間には、これらの指標は適用できない。そのため、街路空間の整備が効果的であるかは明確になっ ていない。整備の効果を計測するためには、流動状況を把握することは重要である。本稿では、歩行空間にお ける流動状況を定量的に表現する指標を提案し、流動状況を単純化した歩行実験によって、その有用性を確認 した。また、複雑な流動を示す実空間においても、適用が可能であることを確認した。また、歩行実験データ を用いて、分析条件や空間条件が流況指標に与える影響についての定性的な知見を得た。

\section{A Study of Pedestrian Flow Index for Grasping Pedestrian Space's Features*}

By Takashi UCHIDA** • Kentaro MATANO*** • Tomoka TSUJI****

Recently, the activation of the urban area is becoming a serious problem. As an example, open terraces are set up to improve the usage of street spaces. The street spaces are evaluated by the index of flowing quantity of the space density and the pedestrians, today. However, these indexes cannot be applied to the space where multiple ways of flow exists. Therefore, it cannot be clarified whether or not if this is effective. So in order to clarify the effect, it is important to understand the situation of the flow. The study proposes the index quantitatively expresses the flow situation.And the utility was confirmed by the walking experiment that simplified the flow situation. Also in an actual urban area that showed complex flow, it was shown that the index was able to be applied. The influence of the analytical condition and the spatial condition on the index was examined by using the walking experiment data. 